Pengembangan Kurikulum Pesantren As-Sunniyyah ..

\title{
PENGEMBANGAN KURIKULUM PESANTREN AS-SUNNIYYAH KENCONG JEMBER
}

\author{
Mohammad Dasuki \\ Fakultas Tarbiyah IAI Al-Falah As-sunniyyah Kencong \\ dasukiahmad09@gmail.com
}

\begin{abstract}
Islamic school as an institution that represents Islamic education in Indonesia has plurality values that should be appreciated. Perspectives on islamic school which are synonymous with conservative ideology and tend to be considered rigid in the face of educational dynamics and the view that pesantren are an ancient institution and only think about the afterlife problems seem to be incorrectly addressed to this islamic school, islamic school As-Sunniyyah Islamic boarding school which is the object of research in this paper is portrait of a islamic school that has successfully organized independent education, including in developing curriculum and learning patterns. The integration between religious and general sciences is the key, in addition to extra activities that encourage students to have multiple talents. The purpose of this study include: 1) obtain information on what causes the development of curriculum in As Sunniyyah Islamic boarding school. 2) reveal the pattern of curriculum development in the As Sunniyyah islamic school.
\end{abstract}

Keywords: Curriculum Development, Islamic Boarding School

\begin{abstract}
Abstrak
Pesantren sebagai institusi yang mewakili pendidikan Islam di Indonesia memiliki nilai-nilai pluralitas yang patut diapresiasi. Perspektif tentang pesantren yang identik dengan ideology konservatif dan cenderung dianggap kaku dalam menghadapi dinamika pendidikan serta pandangan bahwa pesantren merupakan institusi kuno dan hanya memikirkan persoalan akhirat agaknya kurang tepat di alamatkan ke pesantren ini, Pondok pesantren As-Sunniyyah yang menjadi objek penelitian dalam tulisan ini merupakan potret sebuah pesantren yang berhasil menyelenggarakan pendidikan mandiri termasuk dalam mengembangkan kurikulum dan pola pembelajarannya. Integrasi antara ilmu keagamaan dan ilmu umum merupakan kuncinya di samping juga adanya kegiatan-kegiatan ekstra yang memacu santri agar memiliki multi talenta. Tujuan Penelitian ini antara lain: 1) memperoleh informasi apa penyebab dikembangkannya kurikulum di pondok pesantren As Sunniyyah. 2) mengungkapkan pola pengembangan kurikulum pesantren As Sunniyyah.
\end{abstract}

Kata Kunci: Pengembangan Kurikulum, Pondok Pesantren.

Falasifa, Vol. 10 Nomor 2 September $2019 \mid 29$ 


\section{Mohammad Dasuki}

\section{PENDAHULUAN}

Pengkajian mengenai pendidikan formal, terutama yang terkait dengan proses belajar mengajar tidak bisa dipisahkan dari persoalan kurikulum. Kurikulum menjadi semacam barometer tersendiri berhasil tidaknya proses pengajaran. Yang perlu digarisbawahi adalah kurikulum tidak hanya identik dengan satuan mata pelajaran saja. Kurikulum pada dasarnya hanyalah sebuah rancangan yang harus diterapkan pada suatu sistem pendidikan, terlepas bagaimana kondisi sosial politik suatu masyarakat.

Menurut Hilda Taba, seperti dikutip oleh Nasution, kurikulum tidak boleh didefinisikan terlalu luas namun juga tidak terlalu sempit ${ }^{1}$. Semua aspek yang terkait dengan pendidikan seperti metode belajar, sasaran-sasaran pembelajaran, juga termasuk dalam lingkup kurikulum. Dengan merujuk kepada "regulasi akademik" tersebut diharapkan proses pendidikan akan berjalan secara sistematis dan memiliki orientasi yang jelas. Sebab arah pendidikan di samping sebagai media peningkatan penguasaan pengetahuan, kemampuan, dan keterampilan, juga merupakan saranapengembangan nilainilai normatif dalam rangka membentuk jati diri peserta didik $^{2}$.

Bagaimanapun bentuk atau model suatu lembaga pendidikan -termasuk jenis pesantren-, sudah barang tentu menempatkan kurikulum sebagai landasan penting proses belajar mengajar walaupun dalam aplikasi di tingkat institusi berbeda-beda karena disesuaikan dengan kondisi riil suatu lembaga. Meskipun pesantren selama ini dikenal konservatif dan identik dengan wilayah Islam tradisional, pada dasarnya pesantren tetap membuka diri bagi perubahan. Bahkan secara historis, menurut pandangan Nurcholish Madjid pesantren tidak hanya mengandung makna keislaman, tapi juga keaslian indigenous Indonesia ${ }^{3}$.

Pesantren sebagai institusi bersahaja seringkali mendapat stigma miring sebagai kamuflase kehidupan, karena selalu berkutat dengan persoalan akhirat. Kemudian pesantren juga dicerca sebagai pusat kehidupan fatalis, karena perannya memproduksi pola kehidupan yang meninggalkan dunia materi (zuhud). Bahkan yang lebih kasar ialah ketika pesantren dinobatkan sebagai pusat radikalisme, yang menggoyahkan posisi pesantren

${ }^{1}$ S. Nasution, Asas-asas Kurikulum, (Jakarta: Bumi Aksara, 1995), Edisi. 2,Cet.2,hlm.7

${ }^{2}$ Nana Syaodih Sukmadinata, Landasan Psikologi Proses Pendidikan, (Bandung: PT. Remaja Rosdakarya, 2004), hlm.4

${ }^{3}$ Nurcholish Madjid, Merumuskan Kembali Tujuan Pendidikan Pesantren, dalam: Dawam Raharjo (Ed), Pergulatan Pesantren, (Jakarta: Perhimpunan Pengembangan Pesantren dan Masyarakat (P3M), 1985), hlm.3 Falasifa, Vol. 10 Nomor 2 September 2019|30 
Pengembangan Kurikulum Pesantren As-Sunniyyah ...

sebagai kampung peradaban ${ }^{4}$. Kenyataan pahit ini tidak membuat pesantren terkubur lalu hilang dalam cercaan. Hal ini justru memicu kerja keras yang mengubah wajah pesantren semakin tertata dan dewasa dalam menghadapi tuduhan keliru.

Perjumpaan pesantren dengan kurikulum merupakan sebuah keharusan karena kedudukannya yang cukup sentral dalam dunia keilmuan. Menurut Azyumardi Azra, karena kedudukannya sebagai lembaga pendidikan indigenous, pesantren memiliki akar sosiohistoris yang cukup kuat ${ }^{5}$. Dengan bekal tersebut pesantren mampu bertahan di tengah gelombang perubahan berbagai sisi kehidupan menyangkut ekonomi, politik, sosial, dan budaya. Dalam konteks keilmuan, Azyumardi berpendapat paling tidak pesantren memiliki tiga fungsi pokok. Pertama, transmisi ilmu pengetahuan Islam (transmission of Islamic knowledge); kedua, pemeliharaan tradisi Islam (maintenance of Islamic tradition); ketiga, pembinaan calon-calon ulama (reproduction of ulama) ${ }^{6}$. Dilihat dari tanggungjawab pesantren yang cukup besar terhadap tiga hal di atas maka agaknya pembaharuan terhadap kurikulum khususnya aspekpembelajaran merupakan kebutuhan mendesak.

Untuk mengembangkan kurikulum, dibutuhkan prinsip-prinsip praktis dan integral yang dapat memberikan petunjuk pada permasalahan dan pengambilan keputusan tentang tujuan dan langkah yang diperlukan untuk mencapai pendidikan yang efektif dan komprehensif. Menurut pendapat Jusuf Amir, setidaknya ada tiga hal yang harus diperhatikan dalam pengembangan kurikulum, yaitu: ${ }^{7}$ pertama, setiap ilmu memiliki nilai dasar; kedua, proses pembelajaran itu melatih perkembangan dan intelektual; dan ketiga, pendidikan harus memungkinkan dapat dipergunakan atau dapat diaplikasikan dalam kehidupan sehari-hari. Dengan begitu maka manfaat dari pengembangan kurikulum tersebut tidak hanya bagi kalangan pendidikan tapi juga mengakomodir kebutuhan

\footnotetext{
${ }^{4}$ Djohan Efendi, Pesantren dan Kampung Peradaban (Sebuah Pengantar), dalam: Hasbi Indra, Pesantren dan Transformasi Sosial: Studi Atas Pemikiran K.H. Abdullah Syafi ie dalamBidangPendidikan Islam ,'Hasan' M. 'Nur'(Ed), '(Jakarta: 'PENAMADANI), 'Cet.1, 'hlm. 'xvii.' Pesantren' mulai terpojok dan “diburu” ketika wacana tentang terorisme meluas pasca serangan terhadap gedung WTC di Amerika Serikat, yang merupakan symbol ekonomi negara tersebut. Di dalam negeri tragedi Bom Bali dijadikan indikator keberadaan teroris. Bahkan Wakil Presiden RI Jusuf Kalla meminta kalangan pesantren tidak alergi bila semua santri akan diambil sidik jari. Padahal demi rasa keadilan, sejatinya tidak hanya santri yang harus diambil sidik jari tapi seluruh rakyat Indonesia. Lihat juga: Koran Tempo, Edisi Kamis, 8 Desember 2005

${ }^{5}$ Azyumardi Azra, Esei-esei Intelektual Muslim dan Pendidikan Islam, (Jakarta: Logos Wacana Ilmu,1998), Cet.1, hlm. 87

${ }^{6}$ Azyumardi Azra, Esei-esei Intelektual Muslim dan Pendidikan Islam, (Jakarta: Logos Wacana Ilmu,1998), Cet.1, hlm. 89

${ }^{7}$ Jusuf Amir Feisal, Reorientasi Pendidikan Islam, (Jakarta: Gema Insani Press, 1995), cet.1,hlm. 59
}

Falasifa, Vol. 10 Nomor 2 September $2019 \mid 31$ 


\section{Mohammad Dasuki}

mayarakat. Selain itu menurut S. Nasution, ${ }^{8}$ dalam penyusunan dan perencanaan kurikulum sangat membutuhkan pertimbangan psikologis di samping pertimbangan akademis sebagai landasan dasar. Sebab dalam penerapannya kurikulum akan terus berhadapan dengan pribadi yang berbeda-beda. Pertimbangan-pertimbangan pengembangan kurikulum menjadi "menarik" ketika proses tersebut terjadi di dalam institusi bernama pesantren. Karena, segala proses yang berlangsung di pesantren secara hirarkis harus melewati persetujuan pimpinan pondok pesantren yaitu kyai.

Pondok pesantren As Sunniyyah yang akan menjadi objek penelitian ini sudah cukup matang dalam umur 75 tahun. Namun dalam keberadaannya pesantren ini telah melewati berbagai perubahan sosial. Lembaga ini dilahirkan oleh sesosok ulama sekaligus pejuang KH. Jauhari Zawawi yang berasal dari Desa Sedan Kecamatan Sedan Kabupaten Rembang Jawa Tengah, sebagai suatu pengembangan wawasan dan pengembangan daya tampung dengan sistem pendidikan serta pengajaran yang lebih variatif dan memenuhi hajat umat serta memberikan prospek yang sangat baik untuk sebuah sarana pendidikan. Sasaran siswa yang ditargetkan untuk menuntut ilmu di Pondok Pesantren As Sunniyyah bukan hanya warga sekitar pesantren, namun lebih jauh lagi adalah seluruh rakyat Indonesia yang ingin memperdalam ilmu umum sekaligus ingin memahami dan mengamalkan ajaran agama Islam yang baik ${ }^{9}$.

Letak pesantren As Sunniyyah yang berada di antara perbukitan yang hijau dan dialiri sungai, merupakan tempat belajar yang rekreatif dan memukau. Ketika berada dalam pesantren ini akan langsung terasa nuansa religius yang kental. Layaknya pondok pesantren pada umumnya kegiatan keagamaan yang harus dijalankan santri sangat padat; seperti sholat berjamaah lima waktu, membaca al-Qur'an, muhadharah (latihan pidato), dan ditambah lagi dengan kegiatan ekstrakurikuler seperti kepramukaan dan seni beladiri. Sedangkan secara geografis, pondok pesantren As-Sunniyyah ini memiliki tempat yang cukup strategis dan mudah dijangkau oleh masyarakat karean akses anguktan cukup memadai, terletak di desa Kencong kecamatan Kencong kabupaten Jember yang

\footnotetext{
${ }^{8}$ S.Nasution, Asas-asas Kurikulum, (Jakarta: Bumi Aksara,1995),Edisi. 2,Cet.2, hlm. 57

${ }^{9}$ Soleh Rosyad, Kiprah Kyai Enterpreneur: Sebuah Pembaharuan Dunia Pesantren diJember'Editor: 'Nanang 'Tahqiq, 'et.al.,' (Rangkasbitung:LPPMLaTansaMashiro,2005),'Cet.1,'hlm. 96
}

Falasifa, Vol. 10 Nomor 2 September $2019 \mid 32$ 
Pengembangan Kurikulum Pesantren As-Sunniyyah ...

merupakan wilayah selatan kabupaten Jember yang berbatasan dengan kabupaten Lumajang.

Salah satu prinsip pengembangan kurikulum yang rasional adalah prinsip fleksibilitas ${ }^{10}$, yang intinya menjelaskan bahwa kurikulum tidaklah kaku. Dalam tataran praktis dapat diartikan bahwa dalam penyelenggaraan proses pendidikan harus diperhatikan pula perbedaan yang ada. Pesantren misalnya, sebagai sebuah lembaga pendidikan khas Islam tidak biasdipaksakan untuk sepenuhnya mengikuti kurikulum yang digunakan secara luas $^{11}$.

Di dalam Undang-Undang Sistem Pendidikan Nasional No.2 tahun 1989 pasal 37 tentang kurikulum disebutkan sebagai berikut:

"Kurikulum disusun untuk mewujudkan tujuan pendidikan nasional dengan memperhatikan tahap perkembangan peserta didik dan kesesuaiannya dengan lingkungan, kebutuhan pembangunan nasional, perkembangan ilmu pengetahuan dan teknologi serta kesenian, sesuai dengan jenis dan jenjang masing-masing satuan pendidikan ${ }^{12}$.

Nampak jelas dalam undang-undang tersebut ada kalimat "...kesesuaiannya dengan lingkungan, kebutuhan pembangunan nasional... yang dapat ditafsirkan bahwa kurikulum harus disusun atau direncanakan sedemikian rupa sehingga mengakomodir segala sesuatunya tentang lingkungan peserta didik. Lebih spesifik lagi misalnya, salah satu kebutuhan pembangunan nasional adalah sumber daya manusia (SDM) yang berakhlak mulia, dan pesantren memiliki cara sendiri untuk memenuhi kebutuhan itu. Undang-undang yang legitimated ini harus disikapi secara konsisten agar tujuan pendidikan yang "mencerdaskan' bisa terwujud dan bermanfaat bagi semua pihak.

Berangkat dari heterogenitas problematika kurikulum yang dihadapi pesantren selama ini, ada beberapa hal menarik dari pondok pesantren As Sunniyyah yang bagi penulis perlu untuk dicermati .Pertama, daya tahan kurikulum pesantren As Sunniyyah dalam menghadapi perubahan sosial dua dekade terakhir cukup baik dan teruji. Kedua, keberanian pesantren yang langsung memadukan sistem pembelajaran tradisional dengan

\footnotetext{
${ }^{10}$ Subandijah, Pengembangan dan Inovasi Kurikulum, (Jakarta: RajaGrafindo Persada, 1993), Edisi. 1, Cet. 1, hlm.53

${ }^{11}$ Lihat: Mujamil Qomar, Pesantren: Dari Transformasi Metodologi Menuju DemokratisasiInstitusi

${ }^{12}$ Undang-undang Tentang Sistem Pendidikan Nasional (UU RI No.2 Th. 1989) dan Peraturan Pelaksanaannya
}

Falasifa, Vol. 10 Nomor 2 September $2019 \mid 33$ 


\section{Mohammad Dasuki}

kurikulum konvensional patut diberi apresiasi mengingat pesantren As Sunniyyah merupakan kiblat pesantren salaf yang ada dikabupaten Jember. Ketiga, munculnya kompetitor baru dalam bentuk sekolah-sekolah unggulan dengan sistem boarding school yang menawarkan kurikulum internasional di samping penekanan terhadap kajian keagamaan, tidak menyurutkan langkah pesantren As Sunniyyah untuk terus berperan bagi perkembangan pendidikan nasional.

Berdasarkan latar belakang masalah yang telah dikemukakan di atas, maka beberapa masalah yang hendak diteliti teridentifikasi sebagai berikut:

a. Factor penyebab adanya pengembangan kurikulum di pondok pesantren As Sunniyyah

b. Pola inovasi kurikulum yang diterapkan di pondok pesantren As Sunniyyah dalam meningkatkan sistem pendidikannya

Penelitian ini memiliki beberapa tujuan penting, antara lain; pertama, memperoleh informasi apa penyebab dikembangkannya kurikulum di pondok pesantren As Sunniyyah. Kedua, mengungkapkan pola pengembangan kurikulum pesantren As Sunniyyah.

Dengan tercapainya beberapa tujuan tersebut di atas, maka penelitian ini diharapkan dapat memberikan sumbangan pemikiran kepada kalangan akademisi dan penentu kebijakan dalam bidang pendidikan, terutama persoalan kurikulum. Selanjutnya juga semoga memberikan pemahaman dan kesadaran kepada public bahwa persoalan pendidikan merupakan tanggungjawab semua pihak. Selain itu diharapkan penelitian ini dapat bermanfaat sebagai; 1) masukan bagi para pengelola, pecinta pesantren dalam memelihara dan meningkatkan pendidikan di lingkungan pondok pesantren As Sunniyyah, 2) bahan kajian bagi instansi atau lembaga yang terkait fungsinya untuk turut mengelola berbagai kegiatan pendidikan dan pondok pesantren, 3) bahan masukan bagi pengembangan ilmu terutama dalam wawasan keterpaduan wawasan pendidikan sekolah dengan pendidikan pesantren dan keterampilan fungsional sebagai pendidikan luar sekolah.

\section{METODE PENELITIAN}

Penelitian ini berbasis lapangan (field research) dan focus utama penelitian ini yakni kurikulum. Ada pertimbangan penting dalam menentukan objek tersebut, yaitu menyingkap strategi pengembangan kurikulum dan strategi pembelajaran sebuah lembaga pendidikan 
Pengembangan Kurikulum Pesantren As-Sunniyyah ...

bernama pesantren. Hal ini akan memudahkan penulis dalam mengeksplorasi sumbersumber data.

\section{Sumber Data}

Pada dasarnya perolehan data-data penelitian ini bermuara pada dua sumber, yakni sumber primer dan sumber sekunder. Mengenai sumber data primer, penulis melakukan observasi lapangan dan mengolah dokumen-dokumen pondok pesantren As Sunniyyah. Sedangkan data sekunder penelitian ini adalah buku-buku utama yang sangat berhubungan dengan persoalan kurikulum, jurnal-jurnal ilmiah pendidikan, makalah-makalah, informasi sekitar pesantren, serta sumber-sumber lainnya yang terkait dengan penelitian ini, undangundang tentang pendidikan.

Selanjutnya penulis juga melakukan studi eksplorasi ${ }^{13}$, yaitu mengumpulkan berbagai informasi tentang pondok pesantren As Sunniyyah dari aspek kependidikannya sebagai bahan untuk penelitian. Informasi akan penulis lacak dari elemen-elemen penting pesantren AsSunniyyah seperti para tenaga pengajar, pembina/pengelola pesantren, kepengurusan struktural, dan beberapa alumni pesantren tresebut.

\section{Teknik Pengumpulan Data}

Penelitian ini akan menggunakan empat metode pengumpulan data:

a. Metode kajian kepustakaan (library research), yakni mengkaji beragam data tertulis dari para pakar bidang pendidikan terutama pada ruang lingkup kurikulum dan pondok pesantren.

b. Metode wawancara ${ }^{14}$, yaitu mengumpulkan data melalui wawancara dengan pihakpihak yang terkait langsung dengan pondok pesantren, seperti pimpinan, bagian pengembangan pendidikan, para tenaga pendidik, santri, dan alumni. Adapun wawancara tersebut bertujuan untuk semakin memudahkan integrasi data selanjutnya.

c. Metode observasi. Metode ini merupakan metode yang digunakan pada penelitian yang menggunakan pendekatan fenomenologi, karena dengan observasi peneliti yang

\footnotetext{
${ }^{13}$ Winarno Surakhmad, Pengantar Penelitian Ilmiah, Dasar, Metode, danTehnik. (Bandung: Tarsito, 1982), hlm.106

${ }^{14}$ Drs. Riduan, M.B.A., Metode, dan Tehnik Menyusan Tesis. (Bandung: ALFABETA, 2004), hlm. 102. Metode wawancara ini terdiri dari: wawancara terpimpin, yakni mengajukan daftar pertanyaan yang telah disusun, dan wawancara bebas, yakni terjadi Tanya jawab bebas antara pewawancara dan responden, namun tetap dalam kerangka penelitian sebagai pedoman.
} 


\section{Mohammad Dasuki}

dalam hal ini sebagai observer akan dapat melihat secara langsung fenomena-fenomena (gejala-gejala) baik itu yang terjadi pada individu-individu yang diobservasi maupun struktur kerja yang terjadi di lapangan untuk kemudian menjadi acuan data yang siap dijadikan bahan penelitian selanjutnya.

d. Metode dokumentasi. Metode dokumentasi merupakan pengambilan data melalui apa yang telah ada dalam dokumen, baik dokumen yayasan maupun dokumen pondok pesantren AsSunniyyah. Metode dokumentasi menurut Koentjaraningrat adalah Data variable seperti yang terdapat dalam surat, catatan harian, kenang-kenangan, laporan, dan sebagainya ${ }^{15}$.

\section{Teknik Analisis Data}

Dalam penelitian ini data-data yang telah terkumpul, selanjutnya diidentifikasi, diolah menggunakan pola deskriptif analitis lalu diuraikan secara sistematis. Kemudian data tersebut juga akan dielaborasi dengan beberapa pendapat dari para ahli pendidikan yang kompeten dalam bidang kurikulum. Dan terakhir akan dilihat pula bagaimana kondisi objektif yang terjadi di lapangan sebagai bahan pertimbangan jika terkait dengan penelitian ini. Sehingga diharapkan hasilnya lebih kualitatif dan komprehensif.

\section{Pesantren As Sunniyyah di Tengah Perubahan Kurikulum Nasional: Sebuah Tinjauan Historis}

Sebagai sebuah lembaga pendidikan yang secara struktural harus tunduk pada regulasi yang ditetapkan oleh otoritas pemerintah, pondok pesantren AsSunniyyah tidak terlepas dari dinamika perubahan kurikulum secara nasional. Sedikitnya sudah beberapa kali pergantian kurikulum dalam skala nasional yang dialami pesantren As Sunniyyah terhitung sejak pesantren ini berdiri pada tahun 1942 hingga tahun 2017, antara lain; kurikulum 1994 yang menekankan keterpaduan antara tiga lingkungan pendidikan, yaitu lingkungan sekolah, keluarga dan masyarakat.

Selain itu ciri dari kurikulum 1994 adalah lebih menekankan materi pokok dan lebih bersifat memaksakan target bahan ajar sehingga tingkat kemampuan peserta didik

\footnotetext{
${ }^{30}$ Koentjaraningrat, Metode-metode Penelitian Masyarakat, (Jakarta: Gramedia, 1997), hlm.129 Falasifa, Vol. 10 Nomor 2 September 2019| 36
} 
Pengembangan Kurikulum Pesantren As-Sunniyyah ...

terabaikan ${ }^{16}$. Kemudian kurikulum 2004 yang dikenal dengan slogan utama KBK (Kurikulum Berbasis Kompetensi). Ciri dari kurikulum 2004, menurut Hafni Ladjid antara lain; pertama, lebih menitikberatkan pada pencapaian target kompetensi (attainment targets); kedua, lebih mengakomodir keragaman kebutuhan dan sumber daya manusia yang tersedia; ketiga, memberikan kebebasan yang lebih luas kepada pelaksana pendidikan di lapangan (guru) untuk mengembangkan dan melaksanakan program pembelajaran sesuai dengan kebutuhan. Selanjutnya kurikulum pada tahun 2006 adalah KTSP (KurikulumTingkat Satuan Pendidikan) dan ada lagi perubahan pada tahun 2013 denga sebutan kurikulum 13 atau K13.

Adapun kurikulum yang diterapkan di pesantren AsSunniyyah, meskipun tidak mencantumkan label pesantren modern struktur materi umumnya merujuk pada kemenag (sebagai representasi kurikulum nasional), sedangkan materi-materi kepesantrenannya mayoritas mengadopsi model kurikulum Pondok-pondok salaf, lalu disesuaikan dengan kondisi pesantren As Sunniyyah ${ }^{17}$. Mengadopsi bukan berarti mengikuti seutuhnya dan memaksakan, tapi dengan memperhatikan ketepatan, kesesuaian dan keselarasan. Artinya prinsip al-muhafazah alâ al -qadîm al-sâlih wa al -akhdzu bi al-jadîd al-aslạh tetap menjadi pegangan utama dalam melakukan perubahan di pesantren ini $^{18}$.

Keterbatasan demi keterbatasan dijadikan sebagai cambuk penyemangat untuk terus mengembangkan pesantren. Agaknya pepatah yang sering didengungkan almarhum Kyai Jauhari sebesar kepayahan dan kesungguhan hati, sebesar itu pulalah keberuntunganmu ${ }^{19}$ telah meresap ke dalam darah generasi penerusnya. Kemauan pengelola pesantren bersusah payah memberikan sentuhan inovasi terhadap sistem pendidikannya, sangat berpengaruh besar terhadap perkembangan pesantren ini.

\section{Analisis Komponen-komponen Pengembangan Kurikulum di Pondok Pesantren As Sunniyyah}

\footnotetext{
${ }^{16}$ Hafni Ladjid, Pengembangan Kurikulum Menuju Kurikulum Berbasis Kompetensi (Jakarta: Quantum Teaching,2005), cet.1, hlm. 48

${ }^{17}$ Wawancara dengan Bapak Saiful, MA selaku Kepala Madrasah Aliyah As Sunniyyah pada tanggal 19 Agustus 2017

${ }^{18}$ K.H. Abdullah Syukri Zarkasyi, Gontor dan Pembaharuan Pendidikan Pesantren, (Jakarta: PTRajaGrafindo Persada, 2005),Ed. 1, hlm. 125

${ }^{19}$ Soleh Rosyad, Kiprah Kyai Enterpreneur: Sebuah Pembaharuan Dunia Pesantren di Banten Editor:NanangTahqiq,et.al.,(Rangkasbitung: 'LPPM,2005), Cet.1'hlm.269
}

Falasifa, Vol. 10 Nomor 2 September 2019| 37 


\section{Mohammad Dasuki}

Pondok Pesantren As Sunniyyah memiliki kurikulum terpadu antara kurikulum pesantren dan kurikulum pendidikan nasional yang terpadu dalam satu sistem yang integral. Implikasi dari model kurikulum ini adalah penyelenggaraan pendidikan yang mengikuti konsep pendidikan nasional yaitu penyelenggaraan pendidikan tingkat menengah pertama (MTS) atau Madrasah Tsanawiyah (MTs) dan pendidikan tingkat atas (MA) atau Madrasah Aliyah (MA).

Dalam melakukan pengembangan kurikulum sejatinya harus sejalan dengan prinsipprinsip yang telah tertanam dalam kurikulum itu sendiri. Prinsip yang dimaksud adalah kaidah yang secara alami menjiwai sebuah kurikulum ${ }^{20}$. Pondok Pesantren As Sunniyyah dalam mengembangkan kurikulumnya juga menerapkan prinsip-prinsip paten tersebut di samping juga mengedepankan inovasi mandiri. Hal yang terakhir ini dimungkinkan terjadi karena secara geneologis sistem pendidikan yang berlaku di pesantren tidak dapat disejajarkan dengan lembaga pendidikan pada umumnya.

\section{Lembaga-lembaga Fungsional Penggerak Kurikulum dan Pengajaran Pondok Pesantren As Sunniyyah}

\section{Majelis Pengajar}

Majelis Pengajaran adalah salah satu lembaga di dalam Pondok Pesantren As Sunniyyah yang diberi amanat untuk menggerakan aktivitas akademik dan non-akademik yang bersifat formal dan non-formal. Direktorat ini memegang fungsi penelitian dan pengembangan (Litbang) dalam rangka terus mencari terobosan-terobosan baru yang bertujuan untuk peningkatan kualitas guru, kualitas belajar siswa, serta kualitas kegiatan belajar mengajar (KBM) di PPLT, agar terus bergerak menuju perbaikan dan peningkatan.

\section{Majelis Pengasuh}

Majelis pengasuhan adalah salah satu lembaga di Pondok Pesantren As Sunniyyah yang mendidik dan membina secara langsung kehidupan berdisiplin santri dalam asrama dan seluruh kegiatan ekstrakurikuler santri. Majelis Pengasuhan di Pondok Pesantren As Sunniyyah dibagi dalam dua wilayah kerja, untuk peningkatan disiplin dan kontrol santri putra dibawah koordinasi Majelis Pengasuhan Putra sedangkan peningkatan dan pengawasan disiplin santri putri dibawah koodinasi Majelis Pengasuhan Putri. Majelis

\footnotetext{
${ }^{20}$ Oemar Hamalik, Kurikulumdan Pembelajaran, (Jakarta: Bumi Aksara,1995),hlm. 31-32 Falasifa, Vol. 10 Nomor 2 September 2019| 38
} 
Pengembangan Kurikulum Pesantren As-Sunniyyah ...

Pengasuhan dalam skema struktur organisasi Pondok Pesantren As Sunniyyah adalah Direktorat II Bidang Pengasuhan Putra dan Direktorat III Bidang Pengasuhan Putri. Dalam prakteknya Majelis Pengasuhan dalam fungsinya sebagai pembimbing dan fungsi kontrol membawahi beberapa sub bagian yaitu Bagian Pengasuhan, Bagian Nahdha (pengawasan bahasa), Bagian Ubudiah (pengawasan kualitas ibadah santri), Bagian Kesehatan, Bagian Mabikori (pengawas kegiatan kepramukaan), Bagian Keputrian dan Bagian Ekstrakurikuler.

\section{Program-Program Edukatif Penunjang Kurikulum}

\section{Bulan Bahasa (Language Month)}

Untuk menopang pemahaman dan penguasan bahasa Arab dan Inggris, Pondok Pesantren As Sunniyyah melalui Bagian Nahdha dan Markaz Al-Lughah sebagai penggerak disiplin berbahasa setiap tahun secara rutin mengadakan rangkaian kegiatan Language Month. Pada tahun 2016 yang lalu kegiatan edukatif ini mengusung tema Let s Open The World with Language. Dengan motto Practice your language now or never santri diberi motivasi agar mencintai kedua Bahasa tersebut dengan cara menggunakannya dalam percakapan sehari-hari.

2. Bulan Pustaka

Salah satu program bagian perpustakaan Pondok Pesantren As Sunniyyah dalam menstimulasi minat baca santri yaitu diselenggarakannya bulan pustaka. Tujuan kegiatan yang dilaksanakan setiap tahun ini adalah menanamkan dalam jiwa santri kecintaan terhadap membaca dan memperdalam ilmu pengetahuan, sehingga melahirkan santri yang memiliki kapasitas intelektualitas (IPTEK) dan spiritualitas (IMTAK) yang mumpuni. Program Bulan Pustaka ini diisi dengan beberapa kegiatan edukatif, di antaranya: Perlombaan karya tulis. Bedah buku. Lomba majalah dinding, resensi buku, Membuat biografi tokoh, Mengarang cerpen. Debat ilmiah, Membuat artikel.

3. Pelatihan Metodologi Pengajaran Kitab Kuning

Pada September 2015, Pondok Pesantren As Sunniyyah di bawah koordinasi Bagian Pengajaran Pesantren bekerjasama dengan Yayasan Darul Falah melaksanakan Pelatihan Metodolgi Pengajaran Kitab Kuning dengan metode amtsilati. Kegiatan ini adalah salah satu program pesantren dalam rangka peningkatan kualitas guru, khususnya di bidang

Falasifa, Vol. 10 Nomor 2 September 2019| 39 


\section{Mohammad Dasuki}

kajian kitab kuning. Sasarannya adalah para guru bidang studi pesantren yang berjumlah 76 orang. Pelatihan ini bertujuan untuk memberikan bekal tambahan pengetahuan tentang metodologi pengajaran dan cara membaca kitab kuning. Masalah yang dibahas meliputi Nahwu, Alfiyah, Sharaf, Metodologi Translitrasi Kitab Kuning, dan Metodologi Pengajaran Kitab Kuning.

4. Lomba Science Antar Konsulat (Asal Daerah)

Untuk mempererat silaturahmi antar santri yang berasal dari berbagai daerah, Pondok Pesantren As Sunniyyah juga rutin mengadakan kegiatan perlombaan Science antar konsulat. Semuanya dalam kerangka peningkatan mutu kurikulum pesantren. Sesuai dengan tujuan pesantren yang ingin melahirkan dan membangun santri yang memiliki militansi dan berakhlak mulia yang berlandaskan prinsip kesinambungan duniawi ukhrawi dibangun pada suatu sistem yang kokoh dan berkesinambungan serta akomodatifterhadap perkembangan global.

5. Diklat Desiminasi Keilmuan

Penyelenggaraan pendidikan yang baik perlu adanya sarana dan prasarana pendidikan yang cukup serta guru yang mempunyai kapabilitas memadai, baik disisi keilmuan maupun teknik mengajarnya.

Atas dasar pertimbangan tersebut Pondok Pesantren As sunniyyah merasa terpanggil untuk melaksanakan program desiminasi keilmuan terhadap sekolah-sekolah (Pesantren atau lembaga pendidikan tradisional) yang ada disekitar pesantren. Dengan harapan program ini akan menjadi instrument pemerataan basic teaching competency dan academic competency bagi guru sehingga dapat maju bersama membangun masyarakat di sekitar sekolah. Sasaran dari kegiatan desiminasi yang kedua ini adalah guru IPA, bahasa dan komputer MA/Pesantren yang ada disekitar Pesantren As Sunniyyah yang belum berkesempatan mengikuti penataran ditingkat pusat. Jumlah pesertanya yaitu 60 orang guru dari MA/pesantren sekitar.

\section{TEMUAN PENELITIAN}

\section{Pengembangan Kurikulum Pendidikan Pesantren}

Tidak jauh berbeda dengan pesantren-pesantren lainnya pesantren As Sunniyyah juga memiliki manajemen dan sarana yang tertata rapi dalam menunjang kegiatan Falasifa, Vol. 10 Nomor 2 September 2019| 40 
Pengembangan Kurikulum Pesantren As-Sunniyyah ...

akademis seluruh santri. Dengan mengadopsi sistem yang biasa diterapkan oleh pesantren lainnya, pesantren As Sunniyyah, dari awal telah menerapkan sistem boarding school yakni santri/siswa harus bermukim di asrama dan santri harus mentaati semua peraturan yang telah ditetapkan. Keunggulan sistem ini antara lain tingkat konsentrasi santri lebih baik dibandingkan dengan bila santri bebas keluar masuk lingkungan pesantren (tidak mukim) atau lebih dikenal dengan istilah santri kalong.

Dengan penerapan sistem mukim ini tidak ada santri yang lepas dari pantauan pengurus dalam menerapkan disiplin keseharian di lingkungan pesantren. Di samping itu dengan mukim, memungkinkan santri untuk mengikuti seluruh kegiatan akademis nonformal guna membekali diri dengan keterampilan pada bidang yang diminati. Seperti yang disampaikan Ust. Imam Syafi'i selaku Pengurus Pondok Pesantren As-Sunniyyah :

"semua santri disini harus berada di pondok pesantren dan mengikuti semua kegiatan yang sudah ditentukan, agar control pengurus lebih mudah dan tidak terlalu terkontaminasi dengan perkembangan zaman yang sifatnya negative yang sangat sulit di kontrol jika berada di luar pesantern"

Pesantren As Sunniyyah sangat disiplin dalam mengawasi gerak santri agar tidak keluar lingkungan asrama dengan bebas. Hal ini sebagai bentuk tanggungjawab untuk menjaga santri dari hal-hal yang tidak diinginkan Bagi santri yang memiliki keperluan keluarga mendesak dan harus pulang, diterapkan mekanisme perizinan yang cukup ketat.

\section{Jenjang Pendidikan, kegiatan Rutin dan kegiatan penunjang}

Terdapat tiga jenjang pendidikan yang harus ditempuh oleh santri Pondok Pesantren As Sunniyyah dalam penyelesaian studi mereka secara tuntas:

\section{a. MTs (Ma had Mutawasithy)}

Program ini diperuntukkan bagi siswa lulusan Sekolah Dasar (SD) atau Madrasah Ibtida'iyah (MI) dengan masapendidikan selama enam tahun, yakni ditempuh dari kelas satu berurutan sampai kelas enam.

b. MA Plus (Ma had Tsanawy)

Program ini diperuntukkan bagi seluruh santri pondok pesantren As Sunniyyah yang melanjutkan studinya pada jenjang pendidikan SMA-nya di Pondok Pesantren As Sunniyyah dan santri pindahan dari Pondok Pesantren lain dengan terlebih dahulu

\footnotetext{
${ }^{21}$ Wawancara dengan Ketua Pengurus Ponpes As Sunniyyah pada tanggal 13 Agustus 2017
}

Falasifa, Vol. 10 Nomor 2 September 2019| 41 


\section{Mohammad Dasuki}

mengikuti tes akademik yang telah ditentukan. Pada jenjang ini ada dua jurusan pendidikan yang dipilih oleh santri yaitu jurusan IPA (Ilmu Pengetahuan Alam) dan jurusan IPS (Ilmu Pengetahuan Sosial)

Adapun kegiatan dapat di deskripsikan gambaran rutinitas santri sebagai berikut; Pukul 04.00-06.00 seluruh santri dibangunkan dari tidur dan langsung menuju masjid untuk melaksanakan sholat shubuh berjama'ah dilanjutkan dengan pemberian kosa kata baru bahasa Arab dan Inggirs atau muhâdatsah bagi santri kelas satu sampai kelas empat, sedangkan santri kelas lima dan enam mengikuti pengajian dan tafsir kitab salafi (Kitab Kuning). Dan kegiatan ini berakhir pada pukul 06.00. Pukul 06.00-06.45 seluruh santri melaksanakan mandi dan sarapan pagi. Pada pukul 06.45 bel berbunyi sebagai tanda masuk kelas dan seluruh santri harus bergegas mengosongkan asrama menuju ruang kelas masingmasing.

Pukul 07.00-12.15 kegiatan belajar mengajar termin pertama dilaksanakan, pada termin ini dilaksanakan dua kali istirahat yaitu pada pukul 08.30-09.00 dan pukul 10.30-1045. Pukul 12.15-14.00 kegiatan belajar mengajar termin pertama selesai, dilanjutkan sholat dzuhur berjama'ah. Setelah itu seluruh santri makan siang dan istirahat. Dan pukul 14.00 bel berbunyi tanda masuk kelas untuk termin kedua.

Pukul 14.15-15.00 seluruh santi harus berada diruang kelas masing-masing untuk melaksanakan kegiatan belajar mengajar termin kedua. Pukul 15.00-17.00 setelah keluar dari ruang kelas dan pulang ke asrama, santri langsung menuju masjid untuk sholat ashar berjama'ah. Selanjutnya seluruh santri istirahat, berolahraga atau mengikuti kegiatankegiatan ekstrakurikuler yang diadakan. Pukul 17.00-17.30 seluruh santri harus menyelesaikan kegiatan mereka yang dilanjutkan makan sore dan mandi. Pukul 17.3019.30 santri bergegas menuju masjid untuk sholat maghrib yang dilanjutkan dengan pengajian halaqâh (kelompok) dengan pengajar masing-masing yang telah ditentukan.

kegiatan di pondok ini sudah full mulai dari santri bangun tidur sampai pada mau tidur lagi, istilah kerennya full day school dan bahkan melebihi dari konsep itu, jadi kalau mau belajar yang full mulai dari pendidikan karakter sampai eksak ya di pondok tempatnya cerita Ustad Abdullah Hamdi ${ }^{22}$.

\footnotetext{
${ }^{22}$ Wawancara Ustad Hamdi pada tanggal 13 Agustus 2017

Falasifa, Vol. 10 Nomor 2 September 2019| 42
} 
Pengembangan Kurikulum Pesantren As-Sunniyyah ...

Beberapa aktifitas penunjang guna meningkatkan yang termasuk dalam kegiatan non-formal pesantren As Sunniyyah antara lain: Kajian kitab-kitab kuning, Pembinaan tilawatil Qur`an, Latihan berpidato dalam tiga bahasa (Arab, Inggris, dan Indonesia), Pusdiklat komputer, Pembiasaan berbahasa Arab dan Inggris dalam komunikasi sehari-hari, Diskusi, penelitian ilmiah dan pengembangan jurnalistik, Kepramukaan dan keputrian (kegiatan khusus santriwati), Pengembangan olahraga dan seni, Pengembangan tahfidul Qur`an, Ikatan beladiri (pagar nusa).

\section{Keadaan Santri, Pengurus, dan Tenaga Pengajar}

\section{a. Keadaan Santri}

Para santri dibina secara intensif selama 24 jam agar memiliki kapasitas ilmu yang berimbang; antara pengetahuan agama dan pengetahuan umum serta dibimbing secara ekstra ketat dalam latihan hidup beragama dan bermasyarakat, sehingga selepas dari Pondok Pesantren As Sunniyyah diharapkan memiliki kesiapan untuk terjun ke masyarakat dengan dapat berperan aktif di segala lini dan dengan berbagai profesi. Jumlah santri saat ini mencapai 2087 santri, berasal dari daerah yang cukup variatif, mulai dari Mereka berasal dari berbagai daerah: Kab. Jember, Banyuwangi, Kudus, Tasikmalaya, lampung, Probolinggo, Rembang, Banyumas, Lumajang dan Bali ${ }^{23}$.

Pembagian santri hanya berdasarkan jenis kelamin yakni santri putra dan santri putri. Klasifikasi ini pun hanya berlaku untuk memetakan jenis kegiatan ektrakurikuler (non-formal)yang bisa diikuti sesuai dengan nilai-nilai kewajaran, dan tidak berlaku bila berkaitan dengan kegiatan belajar mengajar. Sebab kegiatan belajar mengajar hanya diklasifikasi berdasarkan jenjang kelas. Adapun rincian jumlah santri pondok pesantren As Sunniyyah berdasarkan jenis kelamin dan kelas dapat dipetakan seperti pada table berikut:

Tabel 1

Jumlah Santri Pondok Pesantren As Sunniyyah Tahun 2016/2017

Berdasarkan Jenis Kelamin

\begin{tabular}{|c|c|c|c|c|}
\hline No & Jenjang Pendidikan & Laki-laki & Perempuan & Jumlah \\
\hline 1 & Tsanawiyah & 676 & 590 & 1266 \\
\hline
\end{tabular}

\footnotetext{
${ }^{23}$ Sekretariat Pondok, Profil PondokPesantren As Sunniyyah Tahun 2017
}

Falasifa, Vol. 10 Nomor 2 September $2019 \mid 43$ 
Mohammad Dasuki

\begin{tabular}{|c|c|c|c|c|}
\hline 2 & SMU/Aliyah & 360 & 354 & 714 \\
\hline & JUMLAH & $\mathbf{1 . 0 3 6}$ & $\mathbf{9 4 4}$ & $\mathbf{1 . 9 8 0}$ \\
\hline
\end{tabular}

\section{Sumber: Sekretariat pondok pesantren As Sunniyyah}

Tabel di atas memberikan informasi umum mengenai jumlah keseluruhan santri pesantren As Sunniyyah untuk tahun ajaran 2016/2017. Jumlah tersebut dapat berubah sewaktu-waktu mengingat bisa saja ada santri yang dikeluarkan dari pesantren (diberhentikan) karena suatu pelanggaran atas disiplin yang melampaui batas, atau mungkin ada santri baru.

\section{b. Keadaan Pengurus}

Dengan jumlah santri yang terus bertambah setiap tahun tentunya membutuhkan pembinaan yang ekstra dari pihak pengelola pesantren, dan hal ini agaknya sulit untuk dilakukan secara maksimal bila tidak terorganisir. Karenanya, pihak pimpinan membuat kebijakan tentang pengangkatan sejumlah guru/ustadz untuk mengisi struktur kepengurusan umum pesantren yang dapat memperlancar kegiatan keseharian santri. Kepengurusan ini langsung di bawah koordinasi pimpinan/kyai pesantren.

Penyerahan tanggungjawab mengurus asrama ini sekaligus menjadi pengalaman berorganisasi yang konkret bagi santri senior sebelum mereka lulus dan terjun ke masyarakat, karena mereka menangani sekitar $70 \%$ urusan asrama.

Sedangkan pengurus pusat hanya mengurusi $30 \%$ aktivitas dan terfokus pada hal-hal yang berkaitan dengan kebijakan akademik. Pola desentralisasi ini menjadikan santri terbiasa dalam mengurusi persoalan rumit yang terjadi di lingkungan asrama. Namun untuk menghindari senioritas yang berlebihan dalam keseharian di asrama, para pengurus diawasi oleh dewan guru. Artinya setiap individu pengurus juga mesti mempertanggungjawabkan kepengurusan mereka kepada pimpinan pesantren melalui mekanisme yang telah ditentukan.

\section{c. Tenaga Pengajar}

Secara garis besar tenaga pengajar di pesantren As Sunniyyah terdiri dari dua kategori, yakni:

- Pertama, tenaga pengajar yang berasal dari alumni pesantren (baik intern maupun dari pesantren lain). Kelompok ini secara khusus diberi tanggungjawab untuk mengasuh semua mata pelajaran / bidang studi yang berbasis keagamaan atau

Falasifa, Vol. 10 Nomor 2 September 2019| 44 
Pengembangan Kurikulum Pesantren As-Sunniyyah ...

materi-materi pesantren yang mayoritas berbahasa Arab, seperti: Ulûm al hadîts, Bahasa Arab, Nahwu Sharaf, Ushûl al Fiqh, Imla, Mahnfûdzât, Hadîts, dan lain-lain.

- Kedua, tenaga pengajar yang berasal dari berbagai perguruan tinggi negeri dan swasta antara lain; Universitas Jember, IAIN Jember, UIN Maliki Malang, UIN Sunan Ampel Surabaya dan STAIFAS. Mereka adalah tenaga-tenaga pengajar profesional dengan latar belakang sarjana strata satu dan strata dua pada beberapa bidang mata pelajaran umum, seperti: Fisika, Biologi, Kimia, Matematika, dan bidang studi umum lainnya yang sengaja didatangkan ke pesantren ini untuk memaksimalkan kemampuan santri dalam kajian ilmu pasti (exact).

Adapun guru formal yang mengajar baik di MTs maupun di MA sudah memenuhi kualifikasi sebagai guru denga berijazah minimal S1, hal sesuai denganapa yang di sampaikan bapak Saiful, MA. Selaku kepala Sekolah MA As Sunniyyah.

untuk pendidikan formal semua Guru saya wajibkan minimal berijazah S1, dan Alhamdulillah beberapa guru sudah ada yang S2 dan sedang menempuhnya dan rata-rata para guru adalah alumnus perguruan tinggi terkemuka di jawa timur ${ }^{24}$.

Untuk menjaga stabilitas proses belajar mengajar di pondok pesantren As Sunniyyah, maka guru yang berhalangan untuk mengajar karena alasan-alasan yang telah ditentukan oleh pemimpin pesantren seperti sakit, keperluan keluarga, atau ada tugas khusus dari pesantren maka harus melewati prosedur perizinan yang resmi. Izin prosedural yang dimaksud adalah melalui pemimpin pesantren, kemudian setelah mendapatkan rekomendasi dari pemimpin pesantren, guru yang bersangkutan melapor kepada Ketua Bagian Pengajaran, selanjutnya Ketua Bagian Pengajaranmemberikan instruksi kepada staffnya untuk menentukan penggantinya. Setiap guru yang berhalangan mengajar diwajibkan memberikan tugas untuk kelas yang ia ajar. Dengan mekanisme perizinan seperti ini, kekosongan kelas pada saat kegiatan belajar mengajar (KBM) berlangsung dapat diantisipasi, sehingga berjalan dengan lancar.Kekosongan kelas adalah dosa besar, demikian motto guru di pesantren As Sunniyyah ${ }^{25}$.

\footnotetext{
${ }^{24}$ Wawancara dengan Bapak Saiful, MA selaku Kepala Madrasah Aliyah As Sunniyyah pada tanggal 19 Agustus 2017

${ }^{25}$ Sekretariat Pondok, Profil PondokPesantren As Sunniyyah Tahun 2017
}

Falasifa, Vol. 10 Nomor 2 September 2019| 45 


\section{Mohammad Dasuki}

Pesantren As Sunniyyah mencermati urgensi guru dalam proses belajar mengajar dengan cukup baik, salah satunya dengan memberikan penghargaan kepada guru-guru yang berprestasi. Bentuk kepedulian pesantren terhadap guru yang sangat bermanfaat adalah memfasilitaspendidikan bagi guru-guru lulusan pesantren untuk melanjutkan studi mereka kejenjang sarjana penuh (Strata 1$)^{26}$.

"proses regenerasi itu sangat penting dan menjadi salah satu skala prioritas program lembaga, kita selalu memonitor para santri yang punya potensi di bidang keilmuan akan kita dorong dan fasilitasi untuk melanjutkan pendidikan ke tingkat atasnya". Kepala Sekolah MA As Sunniyyah Bapak Saiful MA.

Pesantren As Sunniyyah juga memacu profesionalitas para tenaga pendidiknya dengan mengadakan semacam pelatihan dan kunjungan ke beberapa perguruan tinggi yang kompeten dalam bidang tertentu. Yang jelas semua usaha yang dijalankan pesantren terintegrasi dalam kerangka peningkatan kualitas kurikulum dan pengajaran yang dijalankan. Dengan demikian pemberdayaan guru secara maksimal dapat dikatakan merupakan bagian dari strategi pesantren untuk mempertahankan jatidiri sebagai lembaga pendidikan Islam agar mampu bersaing di tengah perubahan paradigma pendidikan, pola pikir masyarakat, dan arus informasi yang sangat cepat.

\section{Sistem Pendidikan Pesantren}

Pondok pesantren As Sunniyyah dalam hal ini menyelenggarakan sistem klasikal dalam pengajaran dengan menerapkan kurikulum terpadu antara bidang studi umum (yang berafiliasi kepada kemenag) dan bidang studi agama(kurikulum pesantren) yang diadopsi dari pondok-pondok salaf dalam satu sistem yang terpadu secara integral. Dengan kombinasi tersebut para santri dibina secara intensif agar memiliki kapasitas keilmuan yang berimbang antara pengetahuan agama dan pengetahuan umum serta dibimbing di lingkungan pesantren secara ekstra dalam latihan hidup beragama yang khusyu dan bermasyarakat. Dengan pembelajaran konkret sedemikian rupa para alumni yang tamat dari lembaga ini diharapkan memiliki kesiapan untuk berbaur ke dalam masyarakat yang memiliki tingkat heterogenitas tinggi, dengan terjun ke berbagai profesi. Tentu tidak berakhir sampai titik ini, pesantren juga berharap alumni yang dilahirkan mampu

\footnotetext{
${ }^{26}$ Wawancara dengan Bapak Saiful, MA selaku Kepala Madrasah Aliyah As Sunniyyah pada tanggal 19 Agustus 2017

Falasifa, Vol. 10 Nomor 2 September 2019| 46
} 
Pengembangan Kurikulum Pesantren As-Sunniyyah ...

meneruskan pendidikan mereka ke perguruan tinggi, agar proses pendewasaan wawasan senantiasa dinamis. setelah hampir 7 tahun berdiri formal di pondok pesantren AsSunniyyah ini, alhamdulillah semakin padu integrasi kurikulum pesantren dan formal, sehingga satu dengan yang lainnya saling melengkapi ${ }^{27}$

Dalam penyelenggaraannya, kuriukulum di Pondok Pesantren As Sunniyyah terbagi atas intra kurikuler, ko-kurikuler dan ekstra kurikuler. Intra kurikuler merupakan kegiatan yang melibatkan tenaga pengajar secara langsung dengan sistem klasikal. Ko-Kurikuler merupakan kegiatan tambahan santri (muatan lokal) yang wajib diikuti seperti muhadharah (berlatih khutbah) dalam tiga bahasa, Mafahim (cerdas cermat), pelatihan komputer, keputrian, dll. Sedangkan ekstra kurikuler merupakan kegiatan yang boleh dipilih oleh santri dengan tidak mengesampingkanintra maupun ko-kurikuler ${ }^{28}$. Dapat dikatakan kegiatan intrakurikuler dan ko-kurikuler bersifat weajib sedangkan kegiatan ekstra kurikuler sifatnya sunah karena hanya penunjang kreatifitas santri.

Pesantren As Sunniyyah memiliki komitmen yang tinggi dalam hal pembenahan terhadap kurikulum. Hal ini terlihat dari dibentuknya bagian khusus yang menangani persoalan kurikulum. Bagian ini memiliki tugas memantau pelaksanaan kurikulum yang diterapkan pesantren, dan menginventarisir problematika yang akan dievaluasi setiap tahunnya. Evaluasi dilaksanakan dengan cara mengadakan sidang dengan agenda pembahasan segala sesuatu yang terkait dengan pelaksanaan kurikulum, mulai dari struktur bidang studi untuk setiap jenjang kelas, sistem pembelajaran, penyusunan silabus, sampai dengan menentukan layaktidaknya suatu bidang studi untuk tetap diajarkan pada periode berikutnya $^{29}$.

Dari paparan data, hasil observasi dan interview diatas, bahwasannya pondok pesantren As Sunniyyah melakukan pengembangan kurikulum disebabkan oleh dua aspek yaitu internal dan eksternal, aspek internal itu dikarenakan kondisi pondok pesantren yang menurun drastis jumlah santrinya, hal ini menjadi puncak pada kurun tahun 2008-2009, sehingga pada tahun 2010 didirikanlah pendidikan formal yang kurikulumnya

\footnotetext{
${ }^{27}$ Wawancara dengan Bapak Saiful, MA selaku Kepala Madrasah Aliyah As Sunniyyah pada tanggal 19 Agustus 2017

${ }^{28}$ Sekretariat Pondok, Profil PondokPesantren As Sunniyyah Tahun 2017

${ }^{29}$ Wawancara dengan Bapak Saiful, MA selaku Kepala Madrasah Aliyah As Sunniyyah pada tanggal 19 Agustus 2017
}

Falasifa, Vol. 10 Nomor 2 September $2019 \mid 47$ 


\section{Mohammad Dasuki}

diintegrasikan dengan kurikulum pondok pesantren, aspek kedua yaitu eksternal, dimana santri yang ditugaskan ke luar daerah untuk menyiarkan agama Islam ternyata masih sangat membutuhkan legalitas berupa ijazah pendidikan formal, karena masayarakat masih berpandangan bahwa salah satu indikasi kemampuan dan kedalaman ilmu adalah dengan ijazah formal.

Sedangkan pola pengembangan kurikulumnya mengintegrasikan antara kurikulum pesantren dan pendidikan formal (kemenag), hal ini juga menjawab kekhawatiran para santri dan alumni akan terkikisnya nilai-nilai murni pesantren, akan tetapi kembali pada awal tujuan berdirinya pendidikan formal, bahwa ini semua sebagai wasilah untuk tafaqquh fid dini.

\section{KESIMPULAN}

Dari paparan di atas dapat disimpulkan bahwa pondok pesantren As Sunniyyah berusaha menghadapi dinamika pendidikan dengan membenahi sistem pendidikannya, yang terfokus pada beberapa hal berikut: Pesantren As Sunniyyah mengembangkan kurikulumnya dengan cara meng-create program-program yang edukatif yang difungsikan sebagai penunjang pelaksanaan kurikulum utama. Inovasi kurikulum yang dijalankan oleh pondok pesantren As Sunniyyah bukan semata-mata karena ingin mengikuti tren sekolah unggulan yang berbasis boarding school. Heterogenitas keilmuan selalu diletakkan pesantren sebagai kekayaan ilmu Tuhan. Sehingga secara moral dan spiritual, dinamika kurikulum di pondok pesantren As Sunniyyah dapat dipertanggungjawabkan dan tidak berbenturan dengan kepentingan berbangsa dan bernegara. Kualitas lulusan yang dihasilkan pesantren As Sunniyyah sampai saat ini cukup memadai. Hal ini dibuktikan dengan daya saing mereka yang baik pada saat memasuki jenjang perguruan tinggi. Selain itu bagi output yang tidak terjun ke wilayah akademis, peran serta mereka dalam masyarakat layak diapresiasi.

\section{DAFTAR PUSTAKA}

Azra, Azyumardi, Esei-esei Intelektual Muslim dan Pendidikan Islam, Logos Wacana Ilmu, Jakarta, 1998, Cet.1

Feisal, Jusuf Amir, Reorientasi Pendidikan Islam, Gema Insani Press, Jakarta, 1995, Cet.1

Falasifa, Vol. 10 Nomor 2 September 2019| 48 
Pengembangan Kurikulum Pesantren As-Sunniyyah ...

Hamalik, Oemar, Kurikulum dan Pembelajaran, Bumi Aksara, Jakarta,1995, cet. 1

Indra, Hasbi, Pesantren dan Transformasi Sosial: Studi Atas Pemikiran

K.H.Abdullah Syafiie dalam Bidang Pendidikan Islam,

'Hasan'M. 'Nur'(Ed), PENAMADANI, Jakarta, Cet.1

Institusi , 'Ed. 'Sayed'Mahdi', 'Erlangga, 'Jakarta.

Koentjaraningrat, Metode-metode Penelitian Masyarakat, Gramedia, Jakarta, 1997

Ladjid, Hafni, Pengembangan Kurikulum Menuju Kurikulum Berbasis Kompetensi,

Quantum Teaching, Jakarta, 2005, cet.1

Madjid, Nurcholish, Merumuskan Kembali Tujuan Pendidikan Pesantren, dalam:

DawamRaharjo (Ed), PergulatanPesantren, Perhimpunan Pengembangan

Pesantren dan Masyarakat (P3M), Jakarta, 1985.

Nasution, S., Asas-asas Kurikulum,Bumi Aksara, Jakarta, 1995, Edisi.2, Cet.2

Qomar, Mujamil, Pesantren: Dari Transformasi Metodologi Menuju Demokratisasi

Riduan, Drs.,M.B.A., Metode dan Tehnik Menyusun Tesis. ALFABETA, Bandung, 2004.

Rosyad, Soleh, Kiprah Kyai Enterpreneur: Sebuah Pembaharuan Dunia Pesantren di Banten ,Editor: Nanang Tahqiq, et.al., LPPM La Tansa Mashiro,Rangkasbitung, 2005,Cet. 1

Subandijah, Pengembangan dan Inovasi Kurikulum, Raja Grafindo Persada, Jakarta, 1993,Edisi. 1,Cet.1

Sukmadinata, Nana Syaodih, Prof.Dr., Landasan Psikologi Proses Pendidikan, PT. Remaja Rosda karya, Bandung, 2004.

Surakhmad, Winarno, Pengantar Penelitian Ilmiah, Dasar, Metode, danTehnik, Tarsito,Bandung, 1982.

Undang-Undang No. 2 Tahun 1989 Tentang Sistem Pendidikan Nasional (UU

RI) dan Peraturan Pelaksanaannya

Zarkasyi, Abdullah Syukri, K.H., Gontor dan Pembaharuan Pendidikan Pesantren, PT Raja Grafindo Persada,Jakarta, 2005,Edisi. 1 